\title{
Modernization, Globalization and Europeanization in the Cities of Anatolia, Turkey in Post 1980s
}

\author{
M. Evren Tok \\ Hamad Bin Khalifa University, Doha, Qatar
}

\begin{abstract}
This study will portray the socio-economic and cultural bases of the alternative modernity claims of three Anatolian cities: Kayseri, Gaziantep and Eskisehir. The intention is to build a picture of the local socio-economic and cultural capacities of these cities and compare them. This comparative analysis will also involve a temporal dimension in the differentiation between the pre-1980s and post-1980s periods. It is hoped that this will offer a better perspective on the different starting points of the cities that resulted from historical levels of state involvement, which in turn produced variation in the formation of industrial and manufacturing capacities. Various practices of market based policies, which influenced the socio-economic conditions in these cities, will be presented to help us conceive of the differential impacts of these policies. Similarly, by looking at export capacities and labor market indicators in each city, we will have a more complete picture of the basis for claims of success. Two external processes, globalization and Europeanization and the changes and transformations they elicited, will also be discussed as additional and significant components in these cities' claims to success.
\end{abstract}

Keywords: local economic development, Anatolian tigers, Turkey, globalization, Europeanization

\section{Introduction}

This study contributes to debates that seek to understand the largely economic transformation that occurred in Anatolia throughout the 1990s and 2000s. One major driver of this transformation was the rapid industrialization of the Anatolian Tigers and their opening up to the world market. In this dissertation, the Anatolian Tigers are understood in a broad sense to include the cities of Kayseri, Gaziantep, Corum, Konya, Eskisehir, and Denizli, all of which have demonstrated notable economic performances beginning in the 1980s. Their success and vitality reveal that there is in fact another Turkey beyond Istanbul, one that is not as backward as is commonly assumed.

The emergence of the Anatolian Tigers as new loci of economic growth and dynamism occurred at a time when the Turkish economy, society and political life were increasingly subject to outside influence. The post-1980s period in Turkey is often characterized by the expansion of globalization, Europeanization and the implementation of market-centered reforms.

In investigating the basis of the claims to "success" of the Anatolian Tigers, it is important to start with the socio-economic context of the cities under investigation. Even though the implementation of market based reforms since their repercussions have had serious effects on the socio-economic landscapes of these cities, it is

M. Evren Tok, Assistant Professor, Public Policy in Islam Program, Qatar Faculty of Islamic Studies, Hamad Bin Khalifa University. 
initially necessary to consider the historical cornerstones of their socio-economic development. After the 1980s, the national state's role in the economy gradually began to decline. Unlike the ISI period, which granted certain benefits through five year development plans, development projects, infrastructure support and public investments, under neo-liberalism the Anatolian cities were expected to survive on their own (Kösebalaban, 2007). This decreasing state involvement should be interpreted in the context of the simultaneous state decentralization process. The resulting decentralization of municipal procurement procedures opened up new opportunities for local businesses. This created new opportunities for local SMEs and enhanced the power of municipal governments in city and local party politics (Eraydin, 1998; Eraydin, 2002). At the same time, the devolution of urban planning to municipalities in the mid-1980s, and the collection of local property taxes meant that the investment by the banks and their regional directorates in municipalities' development expenditures began to shrink. In response, a new form of municipal finance emerged based on the increasing use of foreign credit and participation in international businesses and organizations.

Another important change has been in the increasing use and influence of foreign credit and international institutions in local infrastructure projects' development and funding. In the 1990s and especially in the latter half of the decade, the use of foreign credit in urban projects increased significantly. This new model marked a shift in centre-periphery relations as it allowed municipalities to bypass the center given their direct links with international organizations and banks. In this period, the total international commercial credit used by Turkish enterprises rose dramatically from $\$ 2.6$ billion in the 1990-1995 period to $\$ 6.1$ billion in the $1995-2000$ period. Although this developed into a common practice across the country, with the exception of Gaziantep, Anatolian cities were relatively less enthusiastic about this possibility. Kayseri largely relied on and benefited from workers' remittances from Europe, but this is not counted as credit because this money was primarily transferred through Islamic sects and networks (Demir et al., 2004; Kösebalaban, 2007; Demir, 2005).

Dependence on foreign credit did not always yield positive outcomes. While the total credit used by the Municipality of Gaziantep in the 1995-2000 period amounted to $\$ 45$ million, after the severe financial crises of 2000 and 2001, and the devaluation of Turkish Lira by 50\%, the burden of the debt grew reaching \$300 million in the 2000-2005 period. The fiscal retrenchment of the Guzelbey period (post-2004) and similar municipal practices were enacted in an attempt to eradicate this considerable debt. Eskisehir faced less risk in this regard because the amount of foreign credit owing was low thanks in part to the relatively higher public investment expenditures of the central government.

The level of overall public investment between 1990 and 2010 in these cities was strikingly lower than Istanbul, Izmir and Ankara. ${ }^{1}$ Private sector incentive expenditures followed a similar pattern. Throughout this same period, for instance, Istanbul received almost $20 \%$ of total private investment incentives, Kayseri and Gaziantep received approximately 3\%, and Eskisehir only 1.1\%. This was another cause of the search for alternative methods of capital by the Anatolian cities. These alternative methods, however, were not without their own risks (Ozcan \& Cokgezen, 2003, pp. 14-18).

The considerable debt acquired by cities in a short period of time was one important drawback to financing local activities through international institutions. In 2005, the Greater City Municipality of Gaziantep was $\$ 300$ million in debt to international creditors. ${ }^{2}$ This credit had been used to fund sewage, water treatment

\footnotetext{
${ }_{1}^{1}$ For more information http://www.tuik.gov.tr/sta

${ }^{2}$ Precise names of the institutions were not made public.
} 
and urban development projects. The municipality also had \$20 million in tax debts to the central government. The real problem with this model of financing was that while local businesses benefited from project financing via increased business opportunities and local public procurement, the financial burden and debt of often municipal fiscal regimes was left to local taxpayers, who have little control over municipal finances or affairs.

The impact of the 2000-2001 economic crisis has been identified as a significant factor in the radical decrease in municipal workforce size. This suggests that in some respects, the economic crises were used as justifications for the adoption of increasingly market centered policies. Dogan (2007) identified this tendency in the public speeches of Kayseri Mayor Ozhaseki which touted that his administration ran the municipality much as if capitalists run their companies. Market centered policies allowed the Ozhaseki administration (and other administrations) to justify their policies of downsizing, privatizing, contracting out and making better use of clientelist networks.

In Eskisehir a slightly different pattern emerged. Even though there was still a decrease in the size of the municipal workforce in the post-2000 period, immediately after the election of Mayor Buyukersen, the decline slowed down. As my interview with Tasci (2009), head consultant for Mayor Buyukersen, suggested, this slight decrease during the social democratic Buyukersen period was mostly due to a desire to correct the populist and clientelist hirings of the previous periods, rather than a desire to enact market oriented practices. Overall, in terms of municipal workforces, Eskisehir appears to be least affected.

In the cities of Gaziantep, Kayseri and Eskisehir, as well as the Anatolian Tigers in general, exporting was the common mechanism for generating economic growth. Urban growth coalitions, which became even stronger with the increasing autonomy of municipalities, played a key role in organizing and coordinating local resources in order to pursue aggressive exporting strategies. Exporting strategies have been considered the basis for much of the success claims in these cities. Higher exports and the diversification of target countries are seen as the benchmarks of this growth and success. Even though the average growth rate of the Turkish economy decreased, Kayseri, Gaziantep and Eskisehir were able to maintain the pace of their export-based growth rates. This is due in part to their increasing concentration on foreign rather than domestic markets. Thus, in 2001 while Turkey experienced a negative growth rate of $6.1 \%$ due to the severe financial crisis, the three cities maintained their positive growth rates by relying on exports. This strategy became even more advantageous after the devaluation of the Turkish Lira. The sustainability of real growth rates was doubtlessly crucial for the increases in GDP per capita as this remained higher in the three cities than in national statistics as well. Accordingly, in each city, the contribution of the city economy to the total Turkish GDP gradually increased. In the case of Kayseri, for instance, the city's contribution to the national GDP was $0.67 \%$ in 1990 , but increased to two percent in 2010. Similarly, in Gaziantep it increased from $0.86 \%$ to $2.3 \%$ and in Eskisehir from $0.64 \%$ to $1.6 \%$.

Exports continue to constitute an important share of total production. In Kayseri at the end of 2000, the share of exports to total production reached approximately 30\%, in Gaziantep $40 \%$ and in Eskisehir 25\%. As noted in the previous study, instabilities in domestic markets due to successive financial crises had contributed to an increased emphasis on exports to foreign markets. Allocating local resources to the penetration of foreign markets was seen as a safer strategy for entrepreneurs in these cities.

Another indicator of the importance of an export-oriented strategy has been the increasing number of firms involved in exporting. In 1985, 5.2\% of firms (including both large holdings and SMEs) were involved in 
exporting in Turkey and in Kayseri only four percent of local firms were involved in export. Ten years later, while $14 \%$ of national companies were involved exporting, in Kayseri $25 \%$ of local companies were exporting. By the late 2000s, approximately 30\% of Turkish firms and $45 \%$ of firms in Kayseri were involved in exporting. A similar pattern can be observed in Gaziantep and Eskisehir. These numbers suggest that the three city economies had become deeply entrenched in global markets over time and that their success was increasingly dependent on their exporting performance.

Another indicator that the city economies were becoming more and more export dependent was the portion of exporting firms among each city's total firms. Until 1995, the ratio of total exporting firms to total firms among the Anatolian Tigers was lower than the national average. After 1995, however, when the real growth of Anatolian Tigers began, exporting companies came to occupy a higher place in the city economy as compared to the national economy. The Anatolian cities experienced double digit growth rates in the second half of the 1990s with the economic crisis of 1994 as a crucial stimulator of exports due to the currency devaluations. The signing of the Customs Union agreement with the EU and the ability of Turkish exporters to penetrate the Eurozone without taxes or tariffs was also a key factor in the 1995-2000 period. Simultaneously, as Yildirim (2009) argued, the post-1994 period was troublesome for companies producing for the domestic markets, and widespread shut downs especially among Istanbul-based companies were a prominent cause of the decrease in the total number of firms in Turkey.

\section{External Factors: Globalization and Europeanization}

\section{Globalization and Anatolian Cities}

In Kayseri, the process of globalization can be studied on at least two interrelated levels. The first pertains to the way in which the process of globalization is understood as an economic phenomenon resulting in closer integration into global capitalist flows and greater economic success. Secondly, this economic dynamism has led to a perception that Kayseri's globalization experience is symptomatic of how global capitalism and religion, or globalization and Islamization, can co-exist. Thus, Kayseri has been portrayed as a case in which these seemingly paradoxical processes take place simultaneously. Through the increasing internationalization of the Turkish economy, Kayserian entrepreneurs broadened their horizons beyond national markets and sought opportunities in global markets. During the interviews, there were repeated references to the number of countries Kayseri now exports to as a means of conveying the extent of Kayseri's economic success.

Globalization was a process that allowed Kayserian entrepreneurs to find new niche markets and in their quest to do so culture and religion often played a role since 2000, stagnating European markets have also led Kayserian entrepreneurs to establish new investment strategies in African countries, especially Muslim African nations. The interest in exporting to Muslim African nations can partly be interpreted as a manifestation of cultural affinity. Kayseri GESIAD (Young Businesspeople Association) has been instrumental in establishing these key business relations. Yet not limited to Muslim African nations, looking at the activities of GESIAD since 2002, there is an obvious increase in the number of exhibitions, business involvements and fairs organized between Kayserian entrepreneurs and African business people. Recently, GESIAD organized a "trade and investment" visit to South Africa in November 2009, with the participation of the Minister of Foreign Trade, Zafer Caglayan.

Other similar activities have been arranged including that of the Chief Consultant of the President of Senegal, Moustapha Ndiaye's visit to GESIAD Kayseri in June 2009. His visit was an attempt to build new 
business networks between Senegal and Kayserian entrepreneurs. Ndiaye brought many investment incentives to the table including the provision of free land, customs duties exemptions, tax exemption for five years and infrastructural and technical assistance. Likewise, 50 Nigerian businesspeople were hosted by GESIAD in February 2008, and in December 2007, a group of businesspeople from Egypt visited Kayseri with the intention of establishing new contacts. Overall, there have been an increasing number of Kayserian businesspeople making investments in countries such as Senegal, Sudan, Nigeria and South Africa. A second geographical focus for GESIAD since 2008 has been Latin America, especially Brazil.

The number of countries Kayseri exports to has gradually increased since the 1990s. Export volumes increased as well, reaching approximately 3.5 billion dollars in 2010. When the number of destination countries and export volumes are examined together, it is possible to conclude that globalization brought about a significant diversification of export partners and a host of new geographies for trade relationships. One important effect of having diverse geographies as trading partners has been the ability of Kayserian entrepreneurs to avoid the fragility of domestic markets. As Kilci notes, exporting to global markets has also meant a strong push for local producers to increase their quality and efficiency. In order to be more competitive in the global markets, there was a need for higher quality products and innovation.

For Kayseri, however, the fruits of globalization were not limited to diversification of export markets. Kayserian producers were also the beneficiaries of capital imports that brought with them new technologies and enabled the establishment of more efficient production units. There were also new opportunities for the Chambers of Industry and Commerce, as both became members of the World Chambers Association in 2002. As Kilci from the KTO indicated, subsequent global congresses helped the Chambers to establish new business contacts and enhance their vision for new practices.

Kayseri aspires to produce more technologically intensive goods and to sustain better production standards. Hence, there is an urgent need for the aforementioned learning processes as well as for foreign capital. ${ }^{3}$ Mustafa Boydak, argues that in order to compete in the global economy, Kayseri needs better marketing, technological and investment skills and better access to financial intermediaries. From his perspective, the process of globalization is vital for Kayseri, since the internalization of these skills is possible only through the in-flow of foreign capital and foreign expertise. While for some, the role of foreign capital and foreign presence is still a significant point of debate, most entrepreneurs acknowledge the fruits of the globalization process, and believe that Kayseri's economic resurgence would not have been possible without the liberalization of the economy and the opportunities offered in global markets.

In Gaziantep, the process of globalization, is both similar to and distinct from Kayseri. As in Kayseri, globalization is portrayed as opening opportunities outside of the national economy. Like in Kayseri, entrepreneurs in Gaziantep have found new trading partners: the total number of countries the city exports to reached 142 countries in 2009. This broadening of export destinations along with increasing export volumes meant that exports from Gaziantep exceeded four billion dollars in 2009. Middle Eastern countries, Russia and the Turkic Republics are among Gaziantep's main export markets. As in Kayseri, the share of exports destined for European countries has gradually increased since the 1996 Customs Union Agreement. Nejat Kocer, President of GSO explains this situation as "export mobilization". According to the export mobilization scheme,

\footnotetext{
${ }^{3}$ As Ali Coşkun, former Turkish Minister of Industry and Commerce commented, Kayseri as the "leading" Anatolian Tiger has earned a powerful place in the global integration process with regards to its position as the industrial and commercial center of the Anatolian Region. This has occurred as Turkey seeks to become a center of attraction for foreign as well as domestic investors.
} 
the GSO and GTO provided assistance to firms who sought to produce for foreign rather than national markets. The GSO's support of these firms included quality management, branding, and instruction on how to become more competitive in reaching foreign markets.

An important difference between Gaziantep and Kayseri emerges in terms of city marketing. Urban growth coalitions in Gaziantep have been better able to benefit from the city's historical, economic and cultural potentials. They have also been better equipped with the organizational capacity to establish market centered urban policies, including projects designed specifically to market their city. It is not a surprise that many interviewees identified Trademark City Gaziantep and Innovation Valley, pioneered by the GSO, as evidence of Gaziantep's success in deciphering and following the "globalizing" rules of the game. According to Kocer, President of GSO, the aim of the Trademark City project is to create 100 national brands from Gaziantep, which corresponds to 1,000 new industrial units and employment for 50,000 workers until 2014. This target has been framed by the GSO as falling within the aim of making Antep a national model for Turkey. This strategy is indeed a national model as through Trademark City, Gaziantep has come to rank the fifth in Turkey in terms of the total number of brand registrations. While the total number of brand and patent applications in 2001 was just 353, in 2008 it reached 1650. This is in line with the organizational and institutional capacity acquired through the Trademark City project.

Another difference pertains to Gaziantep's geo-strategic location in the south-eastern region of Turkey. This location was utilized by its urban growth coalition to position Antep as an ideal host of international trade forums and fairs, which have frequently been organized there. The presence of these fairs, expos and forums implies that Gaziantep has become a key city in the Middle Eastern region. This in turn positively influences Turkey's national policy in the region, especially when it comes to Iraq, which has been undergoing a restructuring and "remaking" process for a number of years. Forum Iraq is a crucial component of this scalar strategy. It has been organized on a regular basis since 2004 by the International Forum Iraq Expo and Iraq Ministry of Trade. This expo attracts more than 10 thousand visitors from 45 countries each year and increases Gaziantep's, as well as Turkey's role in the Middle Eastern region. It has also become an important source of leverage in foreign policy issues.

Gaziantep's strategic position in the region fits well with Turkey's increasing foreign policy activism since 2005. As Mehmet Buyukeksi, President of TIM, a national organization that represents the interests of exporters, confirms, Gaziantep has been acting as a coordinator between national actors and neighbor countries helping to initiate dialogue to reverse tensions, especially between Turkey and Syria on certain foreign policy issues. As part of Turkey's national openning to other countries in the region, it has introduced a new incentive scheme for SMEs exporting to Middle Eastern markets, which now receive additional tax incentives and are provided with lower electricity charges.

In Eskisehir, globalization also affected the number and geographical distribution of exporting partners. Unlike Gaziantep and Kayseri, however, the technology content of exports in Eskisehir was traditionally higher and this difference had important implications for Eskisehir's export patterns. According to a recent report published by the Center for Export Improvement (IGEME) in 2009, a national organization under the Ministry of Trade, Eskisehir now ranks third, after Istanbul and Ankara, in terms of the technology content of its exports.

Globalization brought new institutional arrangements for the ETO, Eskisehir Chamber of Trade. The agreement signed between the ETO and the Changzhou Chamber of Trade in 2008 in China is unique in the 
sense that it was the first time a Chamber in Turkey signed a "twin chamber" agreement with a Chinese counterpart. Given that $50 \%$ of Eskisehir's total exports are already destined for EU countries, these agreements are crucial to outward looking entrepreneurs who seek to turn their attention to the "east" rather than the "west" to penetrate the emerging markets of the global economy.

In addition to export patterns, globalization in Eskisehir has had significant impacts on the technological infrastructure of the organized industrial zones (OIZs). Interviews conducted with the ESO confirm that local actors have established a long term organizational focus on global technological enhancements. One of the most common arguments along these lines, best articulated by ESO President Savas Aydemir, is that being successful requires being more innovative, not only in finding new markets, but also in developing innovative products believed to be the strategic weapons of the Eskişehir economy. ${ }^{4}$ The nature of the infrastructural and technical services provided to companies within the OIZs is more sophisticated ${ }^{5}$, and compared to Gaziantep and projects like Trade Mark City and Innovation Valley, Eskisehir has been better able to integrate its technology efforts into production structures and hence exports. In Eskisehir, despite a focus on few sectors and production areas, the relationship between investing more in technological enhancement and their effects on industrial production has been better sustained.

The Eskişehir Commodity and Stock Exchange (ESKTB) is another leading institution in the Eskişehir economy, acting as a pro-globalization and pro-Europeanization agent. It holds the institutional perspective that the latest technological developments in agricultural production should be closely monitored in order to keep up with global transformations and demonstrate progress. The institutional strategy of the ESKTB, with regards to global integration is defined by President Selim Öğütür as, "following the latest developments in mainly the EU and the US, and bringing these technological developments to Eskişehir, while putting great effort into adapting them to local conditions in order to maximize the benefits of the process" (interview with Selim Öğ̈̈tür, conducted on December 3rd 2008, in ETO and ESKTB).

A number of private and public sector initiatives demonstrate the success of global-minded endeavors in Eskisehir. In the post-1985 period, as the Sarar Group witnessed rapid growth and established a partnership with global brand Hugo Boss, it became the pride of both Eskisehir and the nation-state. Its success confirmed that the globalization process provided opportunities and if the necessary organizational and institutional steps were taken, it would be a mutually constituting process, in which urban actors and the globalization process shape each other. Similarly, ETİ Makine Corp., one of the leading machinery sector corporations in Eskişehir, emphasizes the importance of well-established foreign relations. They adhere to the corporate view that global partnerships and the strategic division of labor among parties will raise productivity and profitability, both of which are crucial to making Eskişehir itself a well known global brand (Taşkın \& Beceneli, 2008). Finally, the establishment of the Eskisehir Science Park exemplifies the pursuit of competitiveness in global markets in Eskisehir. The Science Park involves an institute that operates in collaboration with the Open University of Anatolia in Eskisehir. This institute offers programs such as innovation and product development, industrial design, patent/trademark registration, and international law and patent issues, as well as special programs on

\footnotetext{
${ }^{4}$ Interview with Savas Aydemir.

5 The establishment of the Eskisehir Science Park is one example of how competitiveness for global markets is sought after in Eskisehir. The Science Park involves an institute that operates in collaboration with the Open University of Anatolia in Eskisehir. This institute offers programs such as innovation and product development, industrial design, patent/trademark registration, and international law and patent issues, as well as special programs on polymers in the plastics sector.
} 
polymers for the plastics sector.

\section{Europeanization and Anatolian Cities}

The second process contributing to the economic, social and institutional transformation of the three cities is Turkey's relations with the EU have experienced ups and downs and EU membership as a national project has been losing ground in Turkey due to the country's slow adoption of required institutional reforms. The dynamics of Turkey-EU relations and the specificities of this process are beyond the scope of this analysis. There are however two key dimensions of the Europeanization process that are of interest: (1) the involvement of EU-related institutions, such as ABIGEM, Enterprise Europe, and Euro Chambers, and their visibility and significance in Anatolian cities; and (2) the impact of the 1996 Customs Union Agreement, which generated extensive European exporting opportunities for Kayserian entrepreneurs. This section focuses on major activities of these institutions and the ways in which they interact with the socio-economic and local institutional realities of the Anatolian cities. In addition, it seeks to understand why the globalization process is seen as relatively more hazardous by local actors and restricted to the economic realm, while Europeanization has been better able to penetrate other societal realms.

Europeanization has a different type of articulation for local actors in Anatolian cities, because it has also involved the establishment of non-economic connections and interests are also established, especially within municipal affairs and civil society. Thus, the transformative impacts of Europeanization reach more actors. In each city, optimistic perceptions of Europeanization is a common feature, however the institutionalization of the Europeanization process takes place in accordance with the cultural dynamics of the local contexts. In Kayseri, the Europeanization process was rendered most visible through sister city projects with European counterparts, an endeavour that has been much less visible in other cities. The sister city projects can be regarded as a significant push for further communication among cities of diverse geographies. Kayseri became sister city of a German city, Saarbrücken when the protocol was signed by the two Mayors, Mehmet Özhaseki and Michael Burkert (Türkmen, 2007).

Another facet of Europeanization process has been occurring through the establishment of EU Information Offices. These offices have been instrumental in providing guidance and orientation to local civil society groups as well as increasing public awareness of the EU through the implementation of EU funded projects. Not surprisingly projects targeting women's empowerment have become especially visible as representing women's rights according to the criteria for EU integration. The most recent gender project in Kayseri was successfully completed in 2007 and aimed to increase self-awareness among working women over the age of 28 to help them achieve senior level management positions (Kayseri Chamber of Commerce 2008).

The case of Kayseri Young Industrialists and Businessmen Association (GESIAD) is also illuminating.

Namık Subaşı, Secretary General of GESIAD, ${ }^{1}$ Subaşi noted that more than one hundred participants have recently been trained for six months within two fishery projects. These projects have led to the establishment of the greatest cage fishery system in Turkey, the products of which are directly exported to Germany. An additional budget of 100,000 Euros has also been rendered available for industrial design projects under the management of Kayseri GESIAD.

As part of the EU funded projects, it should be noted that the Europeanization process has also opened specific economic opportunity zones. Similar to the municipality's efforts around sister city projects, the Kayseri Metropolitan Municipality has become a leader in helping local entrepreneurs to get the most out of 
these programs by establishing a special institutional structure for EU projects, the Directorate for the EU and Foreign Relations. It was established in August 2006 with the goal of developing projects that benefit from the EU information network and funding. The institution specializes in project preparation and execution. As of the end of 2007, the Kayseri Metropolitan Municipality had been a part of five EU projects and acquired 6,350,000 Euros in funding from the EU. ${ }^{6}$

Finally, the Regional Development Program, co-funded by the EU and the Republic of Turkey and executed by the State Planning Agency (DPT) and the Central Anatolia Development Union (ORAKAB), represents another critical institutional initiative for Kayseri. The program, which commenced in 2006, has become a central component of the regional development strategies of the DPT, which aim to prepare certain regions of Turkey to benefit from EU pre-accession funds by participating in available EU projects. Applied in 13 different cities, including Kayseri, the project has provided technical and practical know-how about EU projects and their funding structures. The program has also strengthened the culture of strategic planning among participants. The financial contribution of the program to the city was notable, as 86 of the 265 projects realized profit, which exceeded their strategic plans. ${ }^{7}$

In Gaziantep, the European Union Business Development Center (ABIGEM) is the central organization for bringing EU "input" into the city. This organization not only helps Antep build business linkages with EU countries, but strengthens Antep's position in the region. The Gaziantep ABIGEM has also been instrumental in realizing the city's regional potential and dynamics. In the textile and food sectors, in particular, ABIGEM has organized Syria-Turkey communication days, which seek to improve business relations between Turkey, Syria and Iraq. Since April 2000, the ABIGEM has organized more than 25 of these meetings and many have explicitly focused on hosting Turcoman Iraqi businesspeople. Likewise, the Gaziantep Business Forum, a sister organization, has been quite active in organizing activities to bring together European and Iraqi companies. In December 2008, a meeting was organized with the participation of 40 European and 140 Iraqi companies.

Two ABIGEM projects in Gaziantep warrant further discussion. These are the Pistacchio Sectoral Project and the Bulgur Sectoral Project. The major objective of the first is to help the pistachio sector expand in order to reach strategic relevance in the region. It also aims to introduce and create awareness of necessary food health and safety standards in line with the EU accession regulatory requirements in Turkey. Currently, 15 companies have been educated and four of those firms have received the Hazard Analysis and Critical Control Points (HACCP) certificate. The second project, the Bulgur Sectoral Project, seeks to increase the efficiency and safety standards of bulgur production in Gaziantep (which constitutes 50\% of Turkey's overall production) to meet EU standards and help producers better communicate with their target markets, wholesalers and intermediaries. To date, 47 companies have received this technical assistance and it has contributed to the total volume of Gaziantep exports, which stand at three million Euros.

As Funda Suran notes, the mission of the Gaziantep ABIGEM is to support local SMEs with a full range of management consultancy, training, and information services to enhance their competitive position and help them to achieve their potential. Among the 13 ABIGEM centers in Turkey, the Gaziantep ABIGEM works as the administrator and coordinator of the others. Funda Suran, head of the Gaziantep ABIGEM, emphasizes a key point in terms of the role of ABIGEMs and the EU's impact in Gaziantep. She claims that investors,

\footnotetext{
${ }^{6}$ For detailed information, see http://www.orakab.gov.tr/

7 For detailed information, see http://www.orakab.gov.tr/
} 
producers and entrepreneurs in Gaziantep have learned in this process that there is indeed a "win-win" model. The Gaziantep Business Forum and ABIGEM's joint efforts to bring together businesses from European countries, Gaziantep and neighboring countries also helps to construct new institutional dialogue and interactions. Intensive demand by Spanish companies to participate in ABIGEM and Business Forum meetings led the Chambers of Trade in Valencia, Madrid and Barcelona to coordinate their activities with the ABIGEM and Gaziantep Chamber of Trade, enabling an institutional rapprochement. Institutions such as the Spanish Institute for Foreign Trade, Med Valencia and Barcelona Activa have likewise sought greater collaboration and coordination with the GTO. In September 2004, Spain's biggest retail chain, El Cortes, organized a "Turkish Products Week" where many companies from Gaziantep presented their products. The world's largest food sector fair, SIAL, has also been hosting more Gaziantep firms than ever before.

Suran's perspective does warrant critical consideration in the sense that, despite the positive perception of local actors, the city's increasing export capacity has not necessarily benefitted the working class to the same extent. Consequently, the EU has attempted to engender its local acceptance through both non-economic and economic transformative interventions, which take into consideration the local socio-economic and institutional realities of the city. Gaziantep's high inflows of migrants from the Eastern regions of Turkey and the increasing social and economic problems experienced by these migrants and their families have been a critical point of concern for the EU. The Economic and Social Integration (EKOSEP) project, in this regard, can be seen as a social compensation mechanism, which tries to address the problems experienced by migrant-workers. Gaziantep is one of four pilot cities participating in the EKOSEP project funded by the EU as a regional initiative to assist cities in the South Eastern region of Turkey in solving issues stemming from increasing migration. Gaziantep was chosen as the hub of the project and has been responsible for the implementation of program in the other three cities. ${ }^{8}$ The overall objective of the project is to initiate local projects mobilized around different urban actors in areas such as economic development, participatory local democracy and infrastructural amelioration, all of which are related to migration in these cities. ${ }^{9}$

Increasing Europeanization thus not only refers to increasing economic linkages, but also to increasing awareness that Gaziantep, as the rising star of the south-eastern region of Turkey, needs to have better solutions to its socio-economic problems including informal/unregulated labor, poor working conditions, and distorted urbanization patterns. As the examples above suggest, the increasing visibility of the EU and its increasing collaboration with the Metropolitan Municipality has created greater awareness of the socio-economic problems encountered as a result of neoliberal globalization.

Eskisehir's Europeanization process is neither limited to the search for new markets and increasing production levels in post-1980s period, nor to hosting pilot projects such as EKOSEP. In Eskisehir the transformative impacts of the Europeanization process are spread through different realms, including various economic sectors, education systems, urban regeneration projects and labor force quality issues. The involvement of the EU in these areas has the objective of ensuring its impacts are not confined to the boundaries of a single institution, but are instituted and organized through the collaboration of various organizations.

\footnotetext{
${ }^{8}$ The other three cities in which the project has been implemented include Sanliurfa, Diyarbakir and Erzurum.

${ }^{9}$ For details, please refer to http://www.ekosep.net/web/projectprovinces/gaziantep. These initiatives also aim to increase the diversity of services provided by local municipalities and increase capacity. There are multiple "pilot" projects in progress in Gaziantep and other EKOSEP cities, including child and youth rehabilitation centers, child-care facilities and increasing support to children of immigrant families. EKOSEP projects largely focus on the younger generation and the social aspect is always privileged.
} 
ESO and ETO's institutional strategies illustrate the versatility of the Europeanization process in Eskisehir. The ESO and ETO have initiated various technical assistance programs designed by the EU. Among these ESO-EU partnerships are the Leonardo da Vinci Vocational Training Program, the EU Active Labor Force Program, and the Strengthening the Vocational Education and Training System in Turkey Program (MEGEP). These programs bring a significant level of know-how to the city; moreover they trigger EU investment in different fields. It is possible to argue that EU involvement is quite compatible with local Eskisehir characteristics, as these European oriented partnerships diagnose and make better use of the relatively better educated and better trained labor force, compared to Kayseri and Gaziantep where fason production and unskilled labor are abundant.

The main activities of the Eskişehir ABİGEM include adjusting the corporate structures and institutional mentalities of Eskişehir firms and SMEs to better match their European counterparts and providing training and consultancy to local firms faced with problems stemming from adaptation to EU legislation. ${ }^{10}$ These characteristics in general are indicative of claims that emphasize Eskisehir's ability to adapt itself to European market norms, which generally reflect market based principles. ${ }^{11}$ Hence, unlike Kayseri and Gaziantep, Eskisehir's share of exports to EU countries is now more than 50\%.

The Europeanization process goes beyond creating new economic geographies as mentioned above, and Eskisehir's record of attracting European capital into the city is more significant than most Anatolian cities. ${ }^{12}$ The institutional efforts pioneered and coordinated by Mayor Buyukersen have sustained the significant flow of European funds into the city. ${ }^{13}$ For instance, the municipality's urban regeneration master plan received significant financial assistance from a leading EU institution, the European Investment Bank (EIB). In the post-2000 period, successive urban projects like the light tram and other infrastructural plans, have been amalgamated into a massive undertaking called the "Urban Development Project" and presented to the EIB, with the aim of obtaining technical and financial assistance. ${ }^{14}$ Also in the case of Eskisehir, credit provision opportunities sustained through European sources have played a more vital role than in the other two cities. The relatively higher number of banks providing credit and international capital in Eskisehir reveal that market-based forms of capital formation are more common in Eskisehir as well.

\footnotetext{
${ }^{10}$ For detailed information see http://www.esabigem.net/sayfa.php?s=1. The institutional counterparts of the ABİGEM are the European Commission, TOBB, ESO and ETO, which share the common view that local SMEs should be supported and encouraged to pursue their sustainable development in international markets

${ }^{11}$ In this respect, Selim Ögütür, the President of ESKTB, reflects this ability by highlighting Eskisehir's focus on significant levels of adaptation to the agricultural regulations of the EU. In light of EU norms on agricultural production, the long term target of the Eskisehir economy is defined as lowering the weight of the total agriculture labor force to seven percent by increasing productivity. According to Selim Ögütür, the resulting labor supply channeled from agriculture to industry should be embraced by a planned urbanization process, which will be the key to the further development of the city in the near future. The mass housing projects of the Eskisehir Metropolitan Municipality enabled the sustainable absorption of incoming populations by the urban center and they are believed to provide a model to many cities.

12 While Turkey in general suffers from low levels of Foreign Direct Investment (FDI), the decision by Germany-based Viessmann Group, a leading international manufacturer of heating systems, to open a factory in Eskisehir is a stark indicator of Eskisehir's progress in terms of providing an attractive space for the foreign investors, developing a vast organized industrial zone equipped with high technological standards and providing favorable parcel rates to domestic and international investors.

${ }^{13}$ Such as Mayor Büyükerşen, who was appointed Head of the Turkish Delegation to the European Council Local Government Initiatives for which he attended meetings in Strasbourg every six months up until 2004. These visits to Strasbourg and subsequent meetings in the EU have had a considerable influence on changes to the urban space of Eskişehir.

14 After a series of visits between the municipal officers and bank representatives from Luxembourg and Eskişehir, the Bank granted a total fund of 120 million Euros to the Eskişehir Metropolitan Municipality in the year 2001.
} 


\section{Conclusions}

This study has described the socio-economic and cultural background of the Anatolian cities before and during the neoliberal globalization process. While there were similarities-less state support, less state-led industrial and manufacturing infrastructure, and growth patterns associated with aggressive exporting strategies, there are also significant differences. For instance, even though Eskisehir had a relatively better base due to the state's industrial investments in the early 1920s and 1930s, all three cities in general suffered from soaring public (municipal) investments and lack of private incentives. In this context, exporting became the most attractive route to deal with the successive crises of the Turkish economy, the accompanying currency devaluations and need for capital accumulation (Boratav, Turel \& Yeldan, 1998; Boratav, Yeldan \& Kose, 2000).

While the number of exporting companies increased substantially in all three cities, the processes of globalization and Europeanization also created numerous other opportunities, such as increasing the diversity of export destination countries and establishing bi-lateral relations at the business association, chamber and municipal levels. These processes confirmed that outward looking Anatolian firms were doing the right thing by producing for external markets, rather than competing in the domestic markets, already fragile due to unemployment, shrinking demand and inflation. As we saw, even for municipal administrations, as in the case of Gaziantep, looking to international opportunities, such as international credit and lending institutions, became an increasingly accessible and necessary option in the post-1980s.

An important finding of this study has been that in explaining the strong export performances of the Anatolian Tigers, the repression of real wages, decreasing unionization and casualization of labor are crucial parameters that warrant further examination. In this setting, even rising productivity levels were often artificial, since inflation led to a bubble economy and the main source of productivity was the erosion of real wages. Consequently, urban growth coalitions benefited not only from increasing export markets, international credit options and EU guidance, but also informal and low-wage labor. While this study portrayed the determinants of the economic success of the Anatolian Tigers by considering a variety of dimensions in comparison to national statistics and trends, the next study will complement this analysis by looking more closely at the urban growth coalitions and the forms of embeddedness they utilize.

\section{References}

Boratav, K., Turel, O., \& Yeldan, E. (1998). Distributional dynamics in Turkey under "structural adjustment" of the 1980s. New Perspectives on Turkey, 11, 43-69.

Boratav, K., Yeldan, A. E., \& Köse, A. H. (2000). Globalization, distribution and social policy: Turkey, 1980-1998. Center for Economic Policy Analysis Working Paper Series, no. 20, February.

Demir, Ö. (2005). Anadolu Sermayesi' ya da 'Islamci Sermaye (Anatolian Capital or Islamist Capital). In Y. Aktay (Ed.), Modern Türkiye'de Siyasi Düsünce (Political thought in modern Turkey) (Vol. 3) (pp. 870-886). Islamcilik (Islamism). Istanbul: Iletisim Publishers.

Demir, O., Acar, M., \& Toprak, M. (2004). Anatolian tigers or Islamic capital: Prospects and challenges. Middle Eastern Studies, 40(6), 166-188.

Dogan, A. E. (2007). Egreti Kamusallı, Kayseri Örneginde Islamcl Belediyecilik (Loose public governance, Kayseri as an example of Islamic municipal governance). Istanbul: Iletisim Yayınları.

Eraydın, A. (1998). Yeni Sanayi Odaklarının Ortaya Çıkmasında Kamunun Düzenlemeve Destekleme Biçimlerinin Katkısı. Paper presented to Yeni Yerel Sanayi Odaklarl Semineri organized by State Planning Organization. State Institute of Statistics and Turkish Capital Market Board, Ankara. 
Eraydin, A. (2002). The local embeddedness of firms in social networks in Turkish industrial districts: The changing roles of networks in local development. In M. Taylor, M (Ed.), Social Capital and the Embedded Enterprise: International Perspectives, forthcoming.

Kösebalaban, H. (2007). The rise of Anatolian cities and the failure of the modernization Paradigm. Critique: Critical Middle Eastern Studies, 16(3), 229-240.

Ozcan, G. B., \& Cokgezen, M. (2003). Limits to alternative forms of capitalization: The case of Anatolian holding companies. World Development, 31(12), 2061-2084.

Tasci, C. (2009). Yılmaz Büyükersen: Zamanı Durduran Saat. Istanbul: Dogan Kitap.

Taşkın, T., \& Beceneli, I. (December 15, 2008). Eskisehir'in Gelecek Stratejisi Inovasyon" [The future strategy of Eskisehir is innovation]. Dünya Gazetesi, 13.

Türkmen, B. (2007). Kardes Sehir Saarbrücken [Sister City Saarbrücken] Garanti Bankası Anadolu Sohbetleri Kayseri Gazetesi Garanti Bank Anatolia Meetings Paper, November: 8.

Yildirim, J. (2009). Income inequality and economic convergence in Turkey: A spatial effect analysis. International Regional Science Review, 2(2), 221-354. 